Soulissa, L. J., Prapunoto, S., \& Kristijanto, A. I. (2020). Perempuan dalam kelindan rumah pengasingan: Sebuah kajian psikoanalitis tradisi humkoit/koin di pulau buru. Indigenous: Jurnal Ilmiah Psikologi, 5(1). 80-92. doi: https://doi.org/10.23917/indigenous.v5i1.11073

\title{
Perempuan dalam Kelindan Rumah Pengasingan: Sebuah Kajian Psikoanalitis Tradisi Humkoit/Koin di Pulau Buru
}

\author{
Lizanty Jelita Soulissa ${ }^{1}$, Susana Prapunoto ${ }^{2}$, \\ A.Ign. Kristijanto ${ }^{3}$ \\ Fakultas Psikologi, Universitas Kristen Satya Wacana ${ }^{1,2,3}$ \\ lizantysoulissalesnussa@gmail.com ${ }^{1}$,prapunoto2007@gmail.com², \\ gus_ign111@yahoo.co.id ${ }^{3}$
}

\begin{abstract}
Abstrak. Tradisi Humkoitlkoin bagi perempuan Pulau Buru pada saat melahirkan dan pasca melahirkan merupakan bentuk kepercayaan terhadap kehadiran leluhur dengan menggunakan ritual smake. Tradisi pengasingan ini merupakan bentuk kearifan lokal yang masih dipertahankan pada era milenium. Penelitian bertujuan menganalisis kebutuhan dan masalah mendasar yang dialami perempuan di rumah pengasingan berdasar kajian psikoanalitis Jung. Metode kualitatif dan teknik studi kasus digunakan untuk menganalisis kebutuhan dan masalah serta nilai-nilai kesejahteraan hidup perempuan dalam pengasingan di Buru Selatan dan Buru Utara. Unit amatan adalah 8 perempuan yang sedang dan pernah dimasukkan dalam rumah pengasingan. Unit analisis mencakup pengalaman psikologis, reaksi emosional, interaksi sistem psiko-spiritual-budaya dan biologis. Hasilnya adalah tradisi turun temurun sebagai warisan budaya sudah membentuk sistem kepribadian melalui ketidaksadaran kolektif. Sekalipun dilakukan melalui keterpaksaan dan ketidakberdayaan, namun arketipe sebagai bagian struktur warisan, dirasakan oleh subjek kajian mampu memberi petunjuk dalam mengatasi situasi yang mengancam, dan membuat individu semakin didominasi perasaan emosional. Arketipe yang dominan pengaruhnya adalah kelahiran, kematian, Tuhan, setan dan orang bijak berpengaruh mengatur tingkah laku. Kajian ini memberi petunjuk pentingnya pemimpin masa depan memerhatikan pemerataan pendidikan. Secara empiris pendidikan diharapkan meningkatkan fungsi kesadaran. Self sebagai proses individuasi diharapkan mampu menyeimbangkan kesadaran dan ketidaksadaran, sehingga dalam mencapai realisasi diri, kepribadian yang sejahtera dapat terintegrasi secara harmonis dalam ego melalui fungsi psikis yang religius.
\end{abstract}

Katakunci: perempuan; rumah pengasingan; humkoit/koin; psikoanalitis; Pulau Buru

Abstract. The Humkoit / coin tradition for Buru Island women during childbirth and postpartum is a form of belief in the presence of ancestors by using a smake ritual. This tradition of exile is a form of local wisdom that is still maintained in the millennium era. The research aims to analyze the basic needs and problems experienced by women in exile homes based on Jung's psychoanalytic study. Qualitative methods and case study techniques are used to analyze the needs and problems and values of the welfare of women in exile in South Buru and North Buru. The observation unit was 8 women who were and had been taken into exile. The unit of analysis includes psychological experiences, emotional reactions, psychospiritual-cultural and biological system interactions. The result is a hereditary tradition as a cultural heritage that has shaped the personality system through collective unconscious. Even though it is done through coercion and powerlessness, but archetypes as part of the structure of inheritance, the subject of the study is felt to be able to give instructions in overcoming threatening situations, and make individua-

$\mathbf{8 0} \mid$ Perempuan dalam kelindan ... 
Is more emotionally dominated. The dominant archetypes of influence are birth, death, God, Satan and the wise influence in regulating behavior. This study gives an indication of the importance of future leaders paying attention to equitable education. Empirically education is expected to improve the function of consciousness. Self as an individuation process is expected to be able to balance awareness and unconsciousness, so that in achieving self-realization, a prosperous personality can be integrated harmoniously in the ego through religious psychic functions.

Keywords: women; house of exile; humkoit / coin; psychoanalysis; Buru Island

\section{PENDAHULUAN}

Indonesia terdiri dari beragam suku dan budaya yang tersebar di sekitar 17.000 gugusan pulau-pulau, dari Sabang sampai Merauke dengan adat-istiadat, bahasa, kepercayaan, tradisi, budaya dan kebiasaan yang berbeda-beda (Aini et al., 2014). Tradisi pengasingan bagi kaum perempuan pada saat melahirkan dan pasca melahirkan, masih sangat sering dijumpai dalam kalangan masyarakat pedalaman nusantara. Pulau Buru merupakan salah satu pulau di kawasan Indonesia bagian timur yang masih mempertahankan tradisi pengasingan bagi perempuan pada saat melahirkan dan pasca melahirkan. Menurut data Badan Pusat Statistik (BPS) Kabupaten Buru (2013), Pulau Buru terbagi atas dua bagian yaitu Kabupaten Buru dan Kabupaten Buru Selatan.

Masyarakat Pulau Buru menyebut tradisi tersebut dengan istilah humkoit/koin. Tradisi humkoitlkoin (rumah sakral), berkaitan dengan kepercayaan masyarakat kepada roh para leluhur yang disebut Ina Kabuki dan pemujaan pada benda-benda (animisme dan dinamisme) yang penganutnya tersebar di seluruh Pulau Buru (Azizah, 2015).

Penelitian Jayanti et al. (2014) mengungkapkan bahwa sebelum perempuan memasuki humkoit/koin (rumah sakral), wajib dilakukan ritual adat yang disebut dengan smake/babento. Smakel babento sendiri merupakan ritual penyerahan diri dan pengucapan sumpah kepada roh leluhur. Orang-orang yang terlibat dalam ritual tersebut harus mengenakan pakaian adat lengkap dengan selempang merah. Upacara penyembuhan ini bertujuan agar pada saat melahirkan perempuan dan bayinya mendapatkan keselamatan atau tidak diganggu oleh roh jahat.

Kondisi fisik dari kawasan permukiman masyarakat pedalaman Pulau Buru, menjadi salah satu faktor yang sangat berpengaruh terhadap pilihan perempuan Pulau Buru untuk tidak melakukan proses melahirkan di Puskesmas. Letak Puskesmas adalah sekitar $127 \mathrm{~km}$, dari permukiman masyarakat Kecamatan Fenafafan ataupun 139 km, dari Kecamatan Fenalaisela. Kedua kecamatan tersebut merupakan perbatasan dari kedua kabupaten di Pulau Buru. Selain harus menempuh jarak waktu yang sangat jauh, jalan yang harus dilalui juga dalam kondisi fisik yang rusak dan bahkan harus melewati sungai. Disamping persoalan letak geografis, persoalan minimnya pengetahuan masyarakat tentang kesehatan juga merupakan faktor lain yang membuat masyarakat enggan melakukan pemeriksaan kesehatan. Setyowati (2016) menyatakan bahwa tradisi pengasingan yang dilakukan terhadap perempuan pada saat persalinan sampai dengan pasca melahirkan dipengaruhi oleh minimnya pengetahuan para perempuan mengenai praktik perawatan persalinan yang sesuai dengan kaidah kesehatan. Selain hal tersebut terdapat beberapa pantangan pada kehamilan dan pasca melahirkan dalam humkoit/koin bagi perempuan Buru yang berkaitan dengan pola makan perempuan dan pola pemberian ASI kepada anak yang dilahirkan selama berada dalam humkoit/ koin. Pada saat berada dalam rumah tersebut, perempuan Buru dilarang mengonsumsi makanan lain selain papeda kasbih, yaitu jenis makanan dari perasan singkong disirami air panas, dan hanya mengandung karbohidrat dan kurang zat besi. Hal tersebut disebabkan oleh rendahnya pengetahuan 
masyarakat tentang pentingnya nutrisi bagi perempuan dan bayi. Informasi tentang ASI eksklusif tidak pernah diperoleh masyarakat di pedalaman ulau Buru. Padahal kualitas kesehatan bayi baru lahir dalam pertumbuhan dan perkembangannya sangat dipengaruhi oleh kualitas ASI yang dihasilkan oleh ibu, dan kualitas ASI sangat ditentukan oleh makanan yang dikonsumsi oleh ibu. Kondisi ini tentu sangat memengaruhi kondisi kesehatan ibu dan bayi yang akan sangat rentan terkena penyakit (Jayanti et al., 2014). Penggunaan jamu untuk perawatan setelah persalinan biasanya menggunakan akar alang-alang (re) yang ditumbuk dan direbus untuk kemudian diminum. Hal ini diyakini dapat membersihkan perut setelah melahirkan dan melancarkan darah yang keluar.

Masalah lainnya yang sering dialami oleh perempuan saat berada dalam humkoit/koit adalah terkait dengan dukungan sosial dari orang-orang terdekatnya seperti suami. Selama 20 hari lamanya perempuan dan bayinya tidak dapat dikunjungi oleh suami dan bahkan orang-orang terdekatnya selain Ibu, dan dukun beranak. Kim et al. (2014) mengungkapkan bahwa dukungan sosial dari suami dan orang tua serta teman memberi dampak pada kesehatan mental. Dukungan sosial merupakan hal yang penting. Sehubungan dengan itu, Nazari et al. (2015) telah melakukan penelitian terhadap perempuan yang baru pertama kali melahirkan (Primigravida) dan menemukan bahwa perempuan membutuhkan dukungan sosial dari suami, teman, tenaga professional kesehatan dan orang penting lainnya guna memfasilitasi, mengadaptasi dan memeroleh kesehatan mental berdasar persepsi masing-masing.

Selain, fenomena ritual smake/babento dalam tradisi humkoit/koin juga terdapat fenomena pemotongan tali pusat bayi yang baru dilahirkan dengan menggunakan mnakut/netat (alat penyayat dari bambu), hal ini terkadang menimbulkan infeksi, karena alat penyayat yang digunakan masih sangat tradisional dan kurang steril. Proses pembersihan sisa darah kotor pasca melahirkan dilakukan di sungai. Fenomena pengasaran/pangi (pengasapan) juga merupakan prosesi penghangatan tubuh bayi dan ibunya. Proses ini ditandai dengan penempelan kain hangat yang telah diasapi diatas kayu yang dibakar pada pojokan humkoit/koin. Pengasaran/pangi (pengasapan) ini umumnya dilakukan agar tali pusar bayi cepat mengering (Eirumkuy, 2013).

Penelitian-penelitian sebelumnya merupakan kajian dari perspektif kesehatan dan budaya. Dalam penelitian ini, penulis mengkaji fenomena perempuan Buru saat melahirkan hingga pasca melahirkan dalam rumah pengasingan dari perspektif psikoanalitis. Kajian psikoanalitis digunakan dalam penelitian ini untuk mendalami pengalaman ketidaksadaran kolektif dan personal perempuan Pulau Buru pada saat proses melahirkan dan pasca melahirkan, yang erat kaitannya dengan kepercayaan masyarakat, yang diturunkan secara turun-temurun dari generasi ke generasi berikutnya. Jung (1986) dalam Alwisol (2019) mengungkapkan bahwa kehidupan psikologis manusia tersusun dari sejumlah sistem yang beroperasi pada tiga tingkat kesadaran yaitu; ego beroperasi pada tingkat sadar, kompleks beroperasi pada tingkat ketidaksadaran pribadi, dan arketipe beroperasi pada tingkat ketidaksadaran kolektif. Kajian psikoanalitis merupakan kajian tentang cara manusia memandang dirinya sendiri melalui berbagai upaya adaptasi yang dilakukan terhadap lingkungan sosial (Jaenudin, 2012). Jung pendiri psikoanalitis tertarik dengan keberadaan dan universalitas berbagai mitos dan simbol di berbagai budaya. Hal ini tampak dalam perhatiannya pada para psikologi. Jung melihat perilaku dan kepribadian manusia dipengaruhi oleh kesadaran dan ketidaksadaran. Ketidaksadaran terdiri dari elemen personal. Menurut Jung hal-hal yang direpresi ataupun disupresi akan tersimpan dalam ketidaksadaran personal. Sementara itu ketidaksadaran kolektif adalah gudang bekas ingatan yang diwariskan oleh leluhur, yang turun temurun memberi gambaran mengenai aspek kehidupan manusia dan diyakini sebagai kebenaran dari generasi ke generasi berikutnya. Beberapa arketipe dapat membentuk kepribadian yaitu persona, anima \& animus, shadow, dan self. Menurut Jung mempertahankan dan mengembangkan 
budaya merupakan bagian dari energi psikis dengan melakukan progresi, sublimasi, regresi, dan supresi yang ditekan ke alam ketidaksadaran. Sublimasi sebagai transfer energi merupakan proses primitif, instinktif dan rendah diferensiasinya ke proses yang lebih kultural, spiritual dan tinggi diferensiasinya (Jaenudin, 2012).

Masalah penelitian ini berasal dari perjuangan yang berimplikasi nyawa, perubahan sistem hormonal bagi perempuan yang melahirkan, namun di Pulau Buru tradisi pengasingan bagi perempuan melahirkan dan pasca melahirkan masih berlaku. Berdasarkan pada realita tersebut maka rumusan masalah yang dirangkum dalam unit analisis pada penelitian ini adalah mengenai beberapa hal berikut ini: 1) Bagaimana pengalaman psikologis, 2) reaksi emosional, 3) interaksi sistem psiko-spiritual-budaya-biologis, 4) kebutuhan dan masalah mendasar yang dialami perempuan saat melahirkan dan pasca melahirkan dalam ritual budaya pengasingan berdasarkan teori psikoanalitis Jung. Kemudian Tujuan dari penelitian ini adalah untuk menganalisis pengalaman psikologis, reaksi emosional, interaksi sistem psiko-spiritual-budaya dan biologis perempuan yang menjalani ritual budaya pengasingan di Kabupaten Buru Selatan dan Kabupaten Buru berdasarkan kajian psikoanalitis Jung.

\section{METODE}

Penelitian ini menggunakan pendekatan kualitatif, dengan teknik studi kasus. Penelitian lebih berpusat pada subjek maupun objek yang memiliki fenomena atau kasus yang unik. Unit amatan dalam penelitian ialah: perempuan hamil berjumlah delapan orang yang sedang dan yang pernah menjalani proses melahirkan dan pasca melahirkan dalam humkoit/koin. Unit analisis mencakup pengalaman psikologis, reaksi emosional, interaksi sistem psikologis, spritual, budaya, dan biologis. Subjek dipilih dengan menggunakan purposive sampling yang didasarkan pada asumsi bahwa subjek tersebut sebagai subjek dalam tema penelitian yang diajukan dan sesuai dengan tujuan penelitian (Creswell, 2015). Pengumpulan data menggunakan teknik wawancara dan observasi. Teknik analisis menggunakan model interaktif dari Miles and Huberman yang memiliki komponen analisis data yang terbagi atas tiga bagian yaitu; reduksi data, penyajian data, dan verifikasi atau penyimpulan data (Herdiansyah, 2010).

\section{HASIL DAN PEMBAHASAN}

Deskripsi mengenai identitas dari kedelapan subjek yang terdiri atas empat subjek penelitian di Kabupaten Buru dan empat subjek di Kabupaten Buru Selatan., serta pengalaman psikologis, reaksi emosional dan interaksi sistem antara psiko-spritual-budaya dan biologis dari kedelapan subjek tersebut dapat disajikan dalam tabel (1) identitas subjek dan table (2) keseluruhan rangkuman deskriptif analisis dari kedelapan subjek penelitian berikut ini

Tabel 1.

Identitas Subjek

\begin{tabular}{llll}
\hline \multicolumn{3}{c}{ Identitas Subjek } \\
\hline Subjek 1 & Subjek 2 \\
Nama & $:$ Ndoli & Nama & $:$ Lin \\
Usia Mengikuti Tradisi & $:$ 16th & Usia mengikuti tradisi & $:$ 29th \\
Agama & $:$ Hindu Adat & Agama & $:$ Kristen Protestan \\
Golongan Adat & : Raja & Golongan Adat & $:$ Raja Tamu
\end{tabular}


3. Perempuan primigravida juga merasa kebingungan dalam hal merawat bayi seorang diri.

4. Perempuan multigravida dan primigravida memiliki ketidaknyamanan dengan kondisi rumah pengasingan yang dingin, kecil dan gelap pada malam hari

\begin{tabular}{|c|c|c|}
\hline & Pendidikan & $\begin{array}{l}\text { Perempuan di Pulau Buru rata-rata menjalani pendidikan } \\
\text { hingga jenjang Sekolah Dasar (SD). }\end{array}$ \\
\hline & $\begin{array}{l}\text { Interaksi sistem } \\
\text { sosial- budaya- }\end{array}$ & $\begin{array}{l}\text { Pada umumnya baik perempuan multigravida dan } \\
\text { primigravida mengalami ketakutan, kecemasaan dan keta- } \\
\text { takutan, kecemasaan dan keterpurukan }\end{array}$ \\
\hline & $\begin{array}{l}\text { psikologi, spiritual } \\
\text { dan biologis }\end{array}$ & $\begin{array}{l}\text { Pemberian ASI yang tidak intens dan konsumsi makanan } \\
\text { pokok berupa singkong, sebagai bahan pangan telah } \\
\text { diwariskan secara turun-temurun. Perempuan tersebut } \\
\text { tetap meyakini adanya suatu kekuatan besar yang mampu } \\
\text { menolong ibu dan bayi. Kondisi berat yang dialami } \\
\text { membuatnya selalu berdoa kepada Tuhan serta leluhur } \\
\text { agar dapat bertahan sampai tradisi ini berakhir. Tradisi ini } \\
\text { dianggap memberikan sukacita kepadanya dan hal yang } \\
\text { sama juga telah dirasakan oleh sebagian besar keluarganya, } \\
\text { sehingga setiap } \\
\text { ritual yang diadakan selama berada dalam rumah tersebut } \\
\text { selalu diikuti olehnya secara intens. }\end{array}$ \\
\hline \multirow[t]{2}{*}{ Mangeswaen } & Kesehatan Fisik & $\begin{array}{l}\text { 1. Dua perempuan multigravida yang diteliti mengalami } \\
\text { gangguan pada pernapasannya. } \\
\text { 2. Dua perempuan primigravida yang diteliti mengalami } \\
\text { perdarahan. }\end{array}$ \\
\hline & $\begin{array}{l}\text { Pengalaman } \\
\text { Psikologis \& Reaksi } \\
\text { Emosional }\end{array}$ & $\begin{array}{l}\text { 1. Perempuan primigravida mengalami ketakutan } \\
\text { dan kecemasan, mengenai tempat pengasingan dan } \\
\text { juga merasakan kebingungan dalam merawat bayi } \\
\text { didalam kondisi pengasingan. Walaupun demikian } \\
\text { para perempuan primigravida tetap merasakan } \\
\text { kebahagiaan karena dapat melahirkan bayinya dengan } \\
\text { selamat. Selain itu perempuan } \\
\text { 2. primigravida juga hanya bisa meletakkan tangan } \\
\text { kanannya kebagian dada sambil menarik nafas dan } \\
\text { kemudian menghembuskannya kembali sambil } \\
\text { tersenyum. }\end{array}$ \\
\hline
\end{tabular}

Kebutuhan atau masalah
1. Perempuan multigravida memiliki keinginan untuk mendapatkan pendampingan dari keluarga seperti orag tua dan terlebih dari suami.

2. Perempuan primigravida memiliki kebutuhan untuk didampingi oleh suami dan orang tuanya, terutama sosok ibu.

Pendidikan Pendidikan yang ditempuh hingga jenjang SD 
sosial-budayapsikologi, spiritual dan biologis -kecemasan akan kondisi rumah dan juga kondisi anak yang dilahirkan. Tradisi humkoit menunjukkan bentuk kesatuan antara masyarakat dengan budayanya. Meskipun berada dalam semua kondisi cemas dan takut selama berada dalam rumah pengasingan, doa selalu dipanjatkan untuk menyerahkan diri kepada Tuhan dan roh para leluhur yang diyakini sebagai penolong. Kehadiran Tuhan dan leluhur dianggap mampu menjamin keselamatannya dan memberikan sukacita. Sehingga akhirnya subjek tetap bertahan dalam situasi tersebut. Selama berada dalam rumah pengasingan, subjek dan bayinya hanya mengkonsumsi kasbi (singkong). Pemberian Asi hanya diberikan seminggu sekali, dan selama periode tersebut bayi hanya mengkonsumsi air rebusan dan tumbukan dari kasbi (singkong).

Hasil penelitian menunjukkan bahwa ada perasaan cemas dan ketakutan ketika mengonsumsi satu-satunya bahan makanan adat yaitu; singkong selama berada dalam rumah pengasingan. Meskipun demikian, keyakinan adat yang telah di turunkan secara turun-temurun dari leluhur bahwa daun singkong dapat memberi nilai ketenteraman dalam hidup, membuat subjek kajian terpaksa mengonsumsinya sekalipun dari segi nutrisi dapat dikatakan malnutrisi bagi perempuan dan bayi yang harus menjalani pengasingan ini (Nurti, 2017; Sediaoetama, 2008) dan bahkan kandungan seyawa sianida dapat beresiko menimbulkan penyempitan \& gangguan pernafasan (Hartati et al., 2008). Keyakinan adat dan pandangan sosial budaya di Pulau Buru meyakini bahwa singkong dianggap memiliki makna yang lebih luas dari sekedar sumber gizi karena dipercaya makanan tersebut merupakan makanan sakral yang dikonsumsi oleh para leluhurnya, hingga diwariskan secara turun-temurun (Jayanti et al., 2014), dan secara langsung telah membentuk sistem kepribadian melalui keidaksadaran kolektif. Jung tahun 1986 dalam Kusuma (2016) mengungkapkan bahwa ketidaksadaran kolektif diperoleh selama pertumbuhan jiwa manusia, mulai dari generasi yang terdahulu dan hal ini merupakan reaksi manusia yang khas semenjak zaman dahulu di dalam manusia menghadapai stuasi-situasi tertentu seperti; kelahiran, kematian, ketakutan, kecemasan, bahaya, perjuangan untuk betahan hidup.

Hasil penelitian juga menunjukkan bahwa tingkat kecemasan dan ketakutan ibu yang baru petama kali melahirkan (Primigravida) lebih kuat dibanding ibu Multigravida, karena dalam proses persalinan pertamanya yang tidak didampingi oleh orang terdekat seperti suami dan orangtua. Dua dari delapan subjek Primigravida berupaya bunuh diri. Hal ini diduga karena ketakutan yang dialami sehubungan dengan belum memiliki pengalaman melahirkan sebelumnya selain kecemasan dan ketakutan dari kompleks masalah lainnya. Sehubungan dengan kecemasan dan ketakutan atau reaksi emosional, (Rusli et al., 2011) mengungkapkan bahwa para remaja yang mengalami proses melahirkan pada usia 12-20 tahun rentan terhadap berbagai perasaan seperti cemas dan takut yang dapat menghasilkan berbagai macam kondisi seperti pendarahan yang sering mengakibatkan adanya kematian, baik terhadap remaja maupun bayi. Novitasari et al. (2013) juga menyatakan bahwa Primigravida cenderung mengalami kecemasan yang lebih tinggi. Sejalan dengan itu, penelitian yang dilakukan oleh Nazari et al. (2015) menyatakan bahwa perempuan Primigravida lebih memerlukan dukungan dari suami, keluarga dan teman bersifat sangat subjektif berdasarkan persepsinya. Hasil penelitian Broadhead et al. (1983); Kim et al. (2014); McLeish dan Redshaw 
(2015) menyatakan bahwa dukungan sosial memberi dampak pada kesehatan mental secara umum, kejadian depresi, tekanan psikologis, ketegangan psikologis, gejala fisik dan penyebab kematian serta mampu memberi ketenangan karena ada pihak yang mendengarkan, dan memeroleh informasi yang diperlukan ketika menjalani proses kelahiran dan daerah tempat melahirkan. Pendapat ini juga didukung oleh penelitian yang dilakukan oleh Menajang et al. (2017) yang menyatakan bahwa dukungan sosial dari suami mampu mengurangi kecemasan pada ibu Primigravida.

Peran dari dukungan keluarga sangat penting dalam rangka pemberian motivasi terhadap perempuan yang mengalami pengasingan khususnya kepada perempuan yang berada dalam rentang usia remaja, yang masih memiliki kerentanan dan minimnya pengalaman dalam berbagai hal, salah satunya dalam hal merawat bayi. Hasil penelitian menunjukkan bahwa salah satu faktor yang mendorong terjadinya kerentanan adalah terkait dengan minimnya kelekatan atau hubungan yang baik dengan orang tua dan minimnya dukungan sosial dari suami kepada subjek. Menurut Syafitri dan Liyanti (2013), kajian psikoanalitis juga menekankan peran dari seseorang baik ibu atau ayah yang dianggap mampu memberikan rasa nyaman dan menjadi figur penyelamat yang dapat membantu, melindungi dan melayani (archetype wise old dan great mother). Dengan demikian, maka, terkait dengan kelekatan dan dukungan sosial dapat dipahami sebagai penjabaran dari archetype wise old dan great mother yang berpengaruh dalam mengatur tingkah laku subjek.

Pengalaman psikologis kedelapan subjek menunjukkan bahwa terdapat upaya subjek untuk menaati serta menjalankan segala sesuatu yang ditetapkan tradisi masyarakat lokal sebagai pedoman dan mengandung nilai-nilai yang diturunkan dari para leluhur. Sebagian besar subjek, baik Primigravida maupun Multigravida menyatakan bahwa keluarga dan masyarakat menjadi sumber pengetahuan mereka akan tradisi tersebut. Pola kehidupan masyarakat Pulau Buru yang menjalankan tradisi pengasingan dalam humkoit/koin dengan taat, menunjukkan bahwa setiap keluarga telah terinternalisasi dengan kepercayaan tersebut. Hal ini menyebabkan tradisi yang dipertahankan turun-temurun sebagai warisan budaya tersebut sudah membentuk sistem kepribadian melalui ketidaksadaran kolektif. Subjek Primigravida yang mengaku menjalani tradisi pengasingan dengan keterpaksaan dan ketidakberdayaan, meyakini cerita-cerita tentang tradisi leluhur tersebut dirasakan mampu memberi petunjuk dalam mengatasi situasi yang mengancam. Keyakinan akan dongeng dan cerita leluhur ini mampu membuat subjek semakin didominasi perasaan emosional. Dalam teori psikoanalitis Jung (1875) dalam Kusuma (2016), struktur warisan tersebut disebut arketipe. Jung dalam Neumann (2015) menyoroti arketipe perempuan yang memiliki great mother sebagai citra primordial jiwa manusia. Konsep great mother ini mengacu pada ritual, mitologi, seni dan catatan mimpi serta fantasi dalam banyak budaya melalui feminitas yang disimbolkan sebagai ibu yang mengasuh, ibu agung, alam, ibu bumi dan merepresentasikan kekuatan dan destruksi, pengasuhan dan ketakutan, serta diturunkan turun temurun. Arketipe tentang great mother dalam ketidaksadaran kolektif menurut psikologi analitis inilah yang diduga membuat perempuan di Pulau Buru memiliki kebertahanan dan kekuatan psikologis menjalani pengasingan. Menurut Alwisol (2019) arketipe dibutuhkan individu untuk mengontrol perasaan, pikiran dan tingkah laku dengan menciptakan kesan tertentu kepada orang lain, dan kesan-kesan tersebut diharapkan dapat berdampak baik terhadap pembentukan kepribadian dan perkembangan individu. Hasil penelitian menunjukkan bahwa proses perkembangan kepribadian tercermin dan dipengaruhi oleh arketipe terkait dengan situasi tertentu (kelahiran, kematian, kepercayaan kepada Tuhan, setan dan orangorang yang dianggap bijak) yang dapat menempatkan para subjek pada tingkat ketidaksadaran kolektif. Hal tesebut terlihat melalui pemaknaan subjek terhadap tradisi pengasingan dalam humkoit! koin. Hal ini sejalan dengan pernyataan Kusuma (2016) yang menyatakan bahwa ketidaksadaran kolektif yang diwarisi dan dimiliki setiap manusia dan ketidaksadaran kolektif, dibuat dari daya- 
daya energi dan kecenderungan-kecenderungan pengorgsanisasian bawaan yang disebut arketipe.

Proses transformasi ke ketidaksadaran kolektif yang diterima melalui para tokoh adat dan keyakinan keluarga tersimpan dalam gudang bekas ingatan yang diwariskan oleh leluhur, yang turun- temurun memberi gambaran mengenai aspek kehidupan manusia. Pengalaman sebelumnya dari keluarga dan kenalan diyakini sebagai kebenaran dari generasi ke generasi berikutnya. Menurut Jung beberapa arketipe yang membentuk kepribadian yaitu persona, anima $\&$ animus, shadow, dan self telah mempertahankan dan mengembangkan budaya pengasingan ini. Pengalaman dalam menjalani pengasingan merupakan energi. Bagi Jung sublimasi sebagai transfer energi merupakan proses primitif, instinktif dan rendah diferensiasinya ke proses yang lebih kultural, spiritual dan tinggi diferensiasinya. Oleh karenanya ritual budaya ini masih dapat dijalani secara turuntemurun.

Jung dalam Sulung dan Saefudin (2015) melalui teori psikoanalitisnya, mengungkapkan bahwa tingkah laku manusia dibimbing oleh masa lalu, lingkungan, ataupun unsur-unsur lain untuk mencapai aktualisasi diri. Jung lebih lanjut menjelaskan bahwa hal tersebut juga tidak terlepas dari persiapan untuk masa yang akan datang.

Jung (1869) dalam Feist dan Feist (2008) menyebut bahwa upaya dalam mempertahankan dan mengembangkan sesuatu dari masa lalu sebagai energi psikis. Sublimasi yang menekan ke ketidaksadaran dan ditransfer ke proses yang lebih kultural, spiritual Perasaan cemas, takut, dan khawatir yang dialami perempuan dalam proses melahirkan adalah sesuatu yang wajar, sebagaimana dinyatakan oleh Ambarwati (2015) bahwa pada saat perempuan atau seorang ibu menjalani proses persalinan terutama saat terjadinya pembukaan perempuan tersebut akan merasa cemas, takut dan khawatir, sekalipun perempuan itu akan tetap berperilaku sesuai dengan apa yang diharapkan oleh lingkungan sosialnya. Hal ini juga didukung oleh teori psikoanalitis Jung (1992) dalam Dhiniah (2013) yang mengungkapkan bahwa kecemasan muncul karena ada sesuatu yang menghalangi ego untuk mencapai suatu tujuan dan ego berusaha untuk memelihara keutuhan dalam kepribadian sebagai sesuatu yang normal yang sebagai bentuk dari potensi diri, yang didasarkan pada pemahaman bahwa kepercayaan terhadap nilai-nilai yang telah diwariskan adalah bagian yang tidak terpisahkan dalam proses individualisasi. Penghayatan, keyakinan, dan pengalaman yang diperoleh dari masyarakat membuat mitos dan simbol berbagai budaya, juga memengaruhi keyakinan, pengalaman dan tingkah lakunya. Pengalaman meyakini pertolongan dan keselamatan dalam melahirkan dalam rumah pengasingan merupakan satu bentuk ketidaksadaran kolektif yang berdasar konsep psikoanalitis diperoleh secara turun-temurun dan memberikan gambaran mengenai aspek kehidupan, yang kemudian dianggap sebagai kebenaran dan diturunkan dari generasi ke generasi selanjutnya atau sublimasi yang menekan ke ketidaksadaran dan ditransfer ke proses yang lebih kultural, spiritual serta lebih tinggi diferensiasinya (Feist \& Feist, 2008). Dengan demikian perilaku yang dimunculkan oleh perempuan dipengaruhi oleh tradisi budaya yang ada, secara langsung merupakan energi yang telah membentuk kepribadian dan perilakunya.

\section{SIMPULAN}

Berdasarkan hasil penelitian dan pembahasan, dapat disimpulkan bahwa pembentukan pengalaman psikologis, reaksi emosi, interaksi sistem antara psikologis, spiritual, budaya dan biologis perempuan hamil, yang dialami oleh para subjek dipengaruhi oleh kepercayaan terhadap leluhur dengan menggunakan ritual mistis yaitu samake, yang telah diturunkan dari zaman dahulu, dan telah membentuk sistem kepribadian para subjek melalui ketidaksadaran kolektif dan personal. Pengaruh arketipe_atau dalam hal ini_ kelahiran, kematian, Tuhan, setan, dan orang bijak (orang tua; ayah, ibu dan suami) sangat berperan penting dalam proses pembentukan perilaku 
subjek. Semua proses transformasi, baik dari tokoh adat maupun keluarga (terutama orang tua) yang diterima sejak anak-anak hingga dewasa tersimpan dalam ketidaksadaran kolektif dalam gudang bekas ingatan sebagai warisan leluhur. Dengan demikian, ketidaksadaran kolektif ini secara turun temurun akan diwariskan sebagai kebenaran dari satu generasi ke generasi berikutnya. Beberapa arketipe membentuk kepribadian yaitu persona, anima \& animus, shadow, dan self telah mempertahankan dan mengembangkan budaya pengasingan ini. Arketipe-arketipe tersebut dianggap mampu memberi petunjuk dalam mengatasi segala hal yang mengancam. Great mother sebagai arketipe berperan mendukung kebertahanan dan kekuatan psikologis selama perempuan Pulau Buru menjalani pengasingan. Pengalaman, reaksi emosional, interaksi lingkungan yang berat dapat diatasi dengan upaya menginternalisasi arketipe ini dan mentransformasinya sebagai energi psikis. Bagi perempuan Pulau Buru yang menjalani ritual ini, pengalaman menjalani pengasingan merupakan energi psikis melalui sublimasi dan sebagai transfer energi merupakan proses primitif, instinktif ke proses yang lebih kultural.

Implikasi dari penelitian ini lebih ditekankan pada masalah psikologis yang dialami oleh perempuan selama berada dalam rumah pengasingan meliputi: kecemasan, ketakutan, keterpaksaan, ketidakberdayaan, rasa bersalah yang kemudian dinyatakan dalam bentuk reaksi emosi yang berbedabeda pada setiap subjek dengan interaksi psikologis, spiritual, budaya dan biologis. Berdasarkan pada penekanan akan masalah psikologis tersebut, maka berikut adalah saran yang dapat diberikan peneliti. Bagi pemerintah pusat dan daerah, yang terkait dengan pemerataan dan peningkatan mutu pendidikan dan kebudayaan di Indonesia khususnya Pulau Buru perlu lebih diprioritaskan.

1. Bagi Dinas Perempuan dan Perlindungan Anak, diharapkan adanya peninjauan lebih lanjut dalam rangka pemberdayaan dan perlindungan baik kepada perempuan dan bayi yang mengalami situasi pengasingan, mengingat akan kondisi tersebut maka dalam peninjauan juga diharapkan adanya edukasi terkait dengan peran dan hak-hak perempuan dan anak.

2. Bagi Dinas Kesehatan, perlu peninjauan lebih lanjut, dalam rangka pengenalan dan tindak interaktif kepada masyarakat di daerah pergunungan mengenai sterilisasi alat-alat yang digunakan dalam menunjang proses melahirkan dan perihal himbauan mengenai konsumsi yang bergizi bagi ibu serta bayi, dan pola pemberian ASI kepada bayi-bayi yang dilahirkan.

3. Bagi peneliti selanjutnya, penelitian ini merupakan sebuah referensi yang akan dijadikan sebagai bekal ilmu pengetahuan, dalam rangka melengkapi hasil penelitian tradisi humkoit/koin yang masih diterapkan sampai dengan saat ini.

\section{REFERENSI}

Aini, N. N., Wakidi, \& Basri, M. (2014). Tradisi upacara nadran pada masyarakat nelayan Cirebon di Kelurahan Kangkung Bandar Lampung. PESAGI (Jurnal Pendidikan Dan Penelitian Sejarah), 2(6). http://jurnal.fkip.unila.ac.id/index.php/PES/article/view/6667

Alwisol. (2019). Psikologi kepribadian (Edisi revisi). UMM Press.

Ambarwati, W. N. (2015). Respon dan koping perempuan Jawa selama proses melahirkan secara normal di Surakarta. https://publikasiilmiah.ums.ac.id/bitstream/handle/11617/5163/16. Winarsih Nur A..pdf;sequence $=1$

Azizah, Z. (2015). Sejarah dan kebudayaan suku Buru Maluku.

90 | Perempuan dalam kelindan ... 
Badan Pusat Statistik (BPS) Kabupaten Buru. (2013). Buru dalam angka: Buru in figures 2013. BPS Kabupaten Buru.

Broadhead, W. E., Kaplan, B. H., James, S. A., Wagner, E. H., Schoenbach, V. J., Grimson, R., Heyden, S., Tibblin, G., \& Gehlbach, S. H. (1983). The epidemiologic evidence for a relationship between social support and health. American Journal of Epidemiology, 117(5), 521-537. https://doi.org/10.1093/oxfordjournals.aje.a113575

Creswell, J. W. (2015). Penelitian kualitatif \& desain riset: Memilih di antara lima pendekatan. Pustaka Pelajar.

Dhiniah, S. (2013). Teori kepribadian Carl Gustav Jung.

Eirumkuy, E. (2013). Suku bangsa di Kabupaten Buru: The tribe in Buru regency. Jurnal Penelitian, 7(5), 122-150. https://kebudayaan.kemdikbud.go.id/bpnbmaluku/wp-content/uploads/ sites/13/2015/03/Telah-di-Publikasikan-Pada-Jurnal-Peneltian-Vol-7-Nomor-5.-EdisiNovember-2013-Untuk-Mendapatkanya-Silakan-Download-di-sini.pdf

Feist, J., \& Feist, G. (2008). Theories of personality. Pustaka Pelajar.

Hartati, I., Kurniasari, L., \& Yulianto, M. E. (2008). Inaktivasi enzimatis pada produksi linamarin dari daun singkong sebagai senyawa anti neoplastik. Momentum, 4(2), 1-6. https://media. neliti.com/media/publications/113672-ID-inaktivasi-enzimatis-pada-produksi-linam.pdf

Herdiansyah, H. (2010). Metodologi penelitian kualitatifuntuk ilmu-ilmu sosial. Salemba Humanika. Jaenudin, U. (2012). Psikologi kepribadian. CV Pustaka Setia.

Jayanti, R. S., Setiawan, M. A., Nurlatu, E. S., \& Suharmiati. (2014). Perempuan si pembawa penyakit ina kabuki: Etnik Buru Kabupaten Buru. Lembaga Penerbitan Balitbangkes.

Kim, T. H., Connolly, J. A., \& Tamim, H. (2014). The effect of social support around pregnancy on postpartum depression among Canadian teen mothers and adult mothers in the maternity experiences survey. BMC Pregnancy and Childbirth, 14(1), 162-170. https://doi. org/10.1186/1471-2393-14-162

Kusuma, Y. H. (2016). Psikologi sastra teori psikoanalisis Carl Gustav Jung (Gambaran umum, konsep, implikasi metodologis, contoh analisis). Fakultas Bahasa dan Seni Universitas Negeri Surabaya. https://www.academia.edu/30093314/PSIKOLOGI_SASTRA_TEORI_ PSIKOANALISIS_CARL_GUSTAV_JUNG

McLeish, J., \& Redshaw, M. (2015). Peer support during pregnancy and early parenthood: a qualitative study of models and perceptions. BMC Pregnancy and Childbirth, 15(1), 257. https://doi.org/10.1186/s12884-015-0685-y

Menajang, N. K., Pondaag, L., \& Kundre, R. (2017). Hubungan dukungan suami dengan tingkat kecemasan pada ibu primigravida trimester iii di puskesmas Sonder. Jurnal Keperawatan UNSRAT, 5(1), 1-4. https://ejournal.unsrat.ac.id/index.php/jkp/article/view/15790

Nazari, M., Ghasemi, S., Vafaei, H., \& Fararouei, M. (2015). The perceived social support and its relationship with some of the demographic characteristics in primigravida pregnant women. International Journal of Nursing and Midwifery, 7(9), 141-145. https://doi.org/10.5897/ 
ijnm2015.0186

Neumann, E. (2015). The great mother: An analysis of the archetype. Princeton University Press.

Novitasari, T., Budiningsih, T. E., \& Mabruri, M. I. (2013). Keefektifan konseling kelompok prapersalinan untuk menurunkan tingkat kecemasan primigravida menghadapi persalinan. Developmental and Clinical Psychology, 2(2), 62-70. https://journal.unnes.ac.id/sju/index. $\mathrm{php} / \mathrm{dcp} / \mathrm{article} / \mathrm{view} / 2578$

Nurti, Y. (2017). Kajian makanan dalam perspektif antropologi. Jurnal Antropologi (JANTRO): IsuIsu Sosial Budaya, 19(1), 1-10. https://doi.org/10.25077/jantro.v19.n1.p1-10.2017

Rusli, R. A., Meiyuntariningsih, T., \& Warni, W. E. (2011). Perbedaan depresi pasca melahirkan pada ibu primipara ditinjau dari usia ibu hamil. Jurnal Insan Media Psikologi, 13(1), 21-31. http://journal.unair.ac.id/downloadfull/INSAN4294-d20193000efullabstract.pdf

Sediaoetama, A. D. (2008). Ilmu gizi: Untuk mahasiswa dan profesi di Indonesia. Dian Karya.

Setyowati, S. E. (2016). Pengasingan wanita melahirkan suku Nuaulu di Dusun Rohua Kecamatan Amahai Kabupaten Maluku. Jurnal Riset Kesehatan, 5(1), 14-20. https://doi.org/https:// doi.org/10.31983/jrk.v5i1.448

Sulung, D., \& Saefudin. (2015). Teori dan pendekatan psikoanalisa (Carl Gustav Jung). Fakultas Dakwah dan Komunikasi Universitas Islam Negeri Walisongo. janganpelitya.blogspot. com/2015/11/teori-dan-pendekatan-psikoanalisa-jung.html

Syafitri, O., \& Liyanti, L. (2013). Arketipe pahlawan Carl Gustav Jung dalam novel Demian: Die geschichte von emil sinclair jugend. lib.ui.ac.id/naskahringkas/2016-03/S52518-Olivia Syafitri 